Volume -X, Issue-01, January-June, 2015

\title{
Bank-Specific Factors Influencing Profitability of Islamic Banks in Bangladesh
}

\author{
MD. MUSTAFIZUR RAHAMAN* \\ SHARMIN AKHTER ${ }^{* *}$
}

\begin{abstract}
This paper aims at empirically studying the impact of some selected bankspecific factors on Islamic banks' profitability. The data for this study covering a period 2009-2013 is obtained from the annual reports of respective Islamic banks. The statistical tool employed is the technique of linear multiple regression analysis. The data-set used in this study involves eight Islamic banks operating in Bangladesh. Empirical results show that bank-size and deposit have significant negative impact on the return on assets (ROA) which is the proxy for Islamic banks' profitability, while equity is found to have positive significant impact. However, loan and expense management are found to be insignificant in affecting the profitability of the banks.
\end{abstract}

Key Words: Profitability, Islamic Banks, Bangladesh, Panel data

\section{INTRODUCTION}

The concept of Islamic banking is not new. Since the mid-70s Islamic banking has expanded to about 70 countries encompassing most of the Muslim world; the coverage includes about 55 developing and emerging market countries and 13 other locations around the world, including Australia, Bahamas, Canada, Cayman Islands, UK and Switzerland. The rampant globalization has put Islamic banks in fierce competition with traditional banks in well-developed financial markets. Bangladesh is one of countries that have well established Islamic banking sector juxtaposed with traditional banking. Beside the inauguration of new banks every now and then, Bangladesh is experiencing the commencement of Islamic banking division by traditional banks alongside their conventional

\footnotetext{
*Assistant Professor, Department of Accounting, Bangladesh University of Business Technology (BUBT), E-mail: mustafizmamun09@gmail.com.

${ }^{* *}$ Lecturer, Department of Accounting, Bangladesh University of Business Technology (BUBT), E-mail: sharmin068@gmail.com.
} 
banking activities. The performances of Islamic banks are not lagging behind the performance of long-existed conventional banks.

As the Islamic banks in the industry are going to face the intense competition in near future, the decision-makers have to know what factors drive the organization to be profitable. Moreover, the policy-makers and other stakeholders of banks will be able to behoove themselves by knowing the determinants of profitability of Islamic banks.

The existing research conducted so far in Bangladesh in Islamic Banking has focused primarily on the fundamental issue underlying interest-free banking. There is hardly any study focusing on profitability-determinants of Islamic Banks in Bangladesh. The present study aims at exploring the major bank-specific factors that influence the profitability of Islamic banks in Bangladesh. More particularly, the study looks into the effects of capital structure, size, deposits, expense management and liquidity on Bangladeshi Islamic banks' profitability.

The paper is divided into five sections. The literature review on determinants of bank's profitability is highlighted in Section 2. Section 3 elaborates the methodology used in analyzing the relationship between the variables used in this study and the performance indicator of Islamic banks. Section 4 enumerates the findings and Section 5 concludes the paper.

\section{LITERATURE REVIEW}

Many researchers including Goddard et al., (2004), Peters et al., (2004), Athanasoglou et al., (2006), Kosmidou et al., (2006) Heffernan and Fu, (2008), have conducted studies to analyze the determinants of the profitability of conventional banks in different countries across the world. A number of study was also conducted in Bangladesh with the same focus like M. N. Abdullah et al., (2014), Mouri Dey (2014), Sohel Saklain (2012), ShrimalPerera et al, (2013), etc. However, there is hardly any study performed focusing on the profitability determinants of Islamic banks in Bangladesh. Therefore, this study is undertaken to throw some fight on the determinants of Islamic Banks in Bangladesh. The study uses return on assets (ROA) reported by the banks a proxy for banks' profitability.

Most of the literature categorizes the determinants of banks' profitability into two parts, namely internal (bank-specific characteristics) and external (macroeconomic). Internal factors are those within the control of the bank and which are mainly influenced by the bank's management decisions and policy- 
objectives while the external determinants are beyond the control of the bank's management.

Macit (2011) used ROE and the ROA as a measure of profitability while examined the macroeconomic and bank specific determinants of profitability in the participating banks in Turkey. The study found the bank specific determinants of profitability; the ratio of non-performing loans to total loans carries a significant adverse effect on profitability. The same result was observed in the study by Davydenko (2010) in the Ukraine. He also concludes that the log of real assets has a significant direct effect on profitability. Ali, Akhtar and Ahmed's (2011) used the return on assets (ROA) and returns on equity (ROE) to identify the influence of macroeconomic factors on banks profitability.

Yilmaz (2013) used panel data from 195 banks between the years 2005 to 2010, to analyze the determinants of profitability of banks in Turkey as well as in eight different countries. The upshots indicated that operating expenses management, credit risk, capitalization, bank size and inflation are important determinants of bank's profitability.

Sufian (2011), in his research on the profitability of bank in Korea, employed the panel data of 10 banks from 1997-2004 to look for the effect of macroeconomic and bank-specific determinants on profitability. The result shows that although the liquidity level was low in the Korean banks, profitability was quite the opposite in the banking sector. The analysisalso revealed that both overhead cost and credit risk have a negative signal for Korean banks' profitability.

Al-Jarrah (2010) attempted to examine the determinants of the banks' profitability in Jordan during the period 2000-2006. The study found that the most crucial internal determinants of the profitability of banks are loans to total assets ratio, the deposit ratio, the capital structure, the operating expenditures ratio and non-operating expenditures ratio.

Alpers (2011) found the size of credit portfolio and loan has negative impact on bank profitability. He also found also that non - interest income and the bank size have a significant and positive effect on the bank profitability.

Z. R. Imad (2011), seeks to investigate the bank-specific determinants of Jordanian Islamic banks' profitability. The researcher used profit margin and return on assets (ROA) as proxy variable for the profitability of banks. Moreover, 
the study employed unbalanced panel data with linear regression model to determine the effect of bank-specific determinants on profitability. The independent variables were bank size, capital adequacy, credit risk, liquidity risk, management efficiency, management expenses, non-interest earning, market concentration, banking-industry size, inflation and economic growth. The outcomes show credit risk has positive impact on Islamic banks' profitability. In addition, the equity to total asset ratio, capital adequacy, and investment to total deposits ratio, management efficiency will lead to greater profit for the Jordanian Islamic banks. However, other factors such as non-interest earning, bank size, and efficiency of management expenses did not have significant impact on return on assets (ROA) and profit margin of Jordanian Islamic banks.

Lipunga (2014) employed correlation and multivariate regression analysis aimed at investigating the profitability of listed commercial banks in developing countries focusing on Malawi over the period 2009 - 2012. The outcomes indicate that liquidity, bank size and management efficiency have a significant impact on ROA where capital adequacy has insignificant effect. Results also reveals that liquidity has insignificant influence on profitability where bank size, capital adequacy and management efficiency influenced ROA significantly.

Putranto et al. (2014) examined the determinants of bank profitability utilizing the panel data of 25 publicly traded Indonesian commercial banks over the period of 2007-2012. The result showed that loan to deposit ratio and market share of credit demonstrated a negative effect on profitability.

Dawood (2014), in his study used ordinary least square (OLS) method aimed to evaluate the profitability of the 23 commercial banks operating in Pakistan over the period of 2009 to 2012. The empirical findings stated that liquidity, cost efficiency and capital adequacy are among those variables that decide the profitability. Other variables like deposits and size of the bank demonstrate no significant impact on Profitability.

\section{RESEARCH METHODOLOGY}

The study population included all the Islamic banks currently operating in Bangladesh. However, considering the issue of availability of data eight banks were selected. Following the literature in this field a suitable model was applied for achieving the research objective. At each stage of the model-building, 
graphical methods and other numerical tests were carried out to establish an acceptable conclusion.

\section{Data Collection}

The data that form a panel data set covering a period of 5 years (2009-2013) consists of 8 selected Islamic banks operating in Bangladesh. The data are obtained from the annual reports of the respective banks. The researchers then computed the required ratios to represent a variable in the study model.

\section{Model Specification}

The model used in the study is based on the empirical works offered by Athanasoglou et al. (2005), Flamini et al. (2009) and Saona (2011). Six predictor variables are included in the analysis.

The empirical model takes the following form:

$\mathrm{k}$

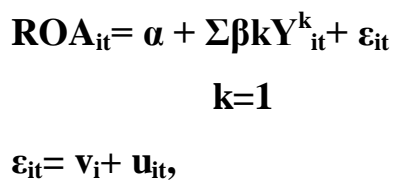

Where, $\mathrm{ROA}_{\text {it }}$ is the return on asset and represents the profitability of bank $\mathrm{i}$ at time $\mathrm{t}$, with $\mathrm{i}=1,2 \ldots \mathrm{N}, \mathrm{t}=1,2 \ldots \mathrm{T}, \alpha$ is a constant term, Yitis a factor of $\mathrm{k}$ predictor variables and citis the disturbance term with viasthe unobserved bank specific effect and uitas the idiosyncratic error. The bank-specific control variables (Ykit) are bank size (natural log of total assets), equity (total equity to total assets), deposit (total deposit to total assets), loan (total loan to total assets), and expenditure management (total operating expense to total assets).

The estimated coefficients measure the degree of association between the predictor variables and the dependent variable. The statistic would be able to highlight the percentage of total diversity in dependent variable justified by the independent variables.

The empirical estimation is also performed by using the least square method of Fixed Effects Model (FEM) to control for bank-specific effects. Hausman (1978), test was applied to take the opportunity to use a fixed effects rather than a random effects model. This study employs Fisher-type test, specifically the ADF unit root test to evaluate the stationarity of the variables in the model. Stationary 
means the mean, variance and autocorrelation of a variable do not change with time. Modified wald test and Wooldridge test was performed to check for heteroskedasticity and autocorrelation respectively. Correlation matrix was used to check for multicollinearity.

\section{Profitability}

As we found in the literature the proxy for bank profitability could be return on assets (ROA), return on equity (ROE) of banks and other financial ratios. However, Imad, 2011; Rashidah et al., 011; Saira et al., 2011; Flamini et al., 2009; Saiful Azhar and Affandi, 2003, used only return on asset as the proxy of banks' profitability in their studies. In addition, Saiful Azhar and Affandi, 2003, said the reason of choosing return of asset over return of equity is because financing was made by Islamic banks from its deposits rather than capital. Therefore, return on assets is a better choice over return on equity. ROA can be calculated by dividing the net profit of bank over its total assets.

\section{Size of banks}

According to Boyd and Runkle, (1993), banks size is expected to promote economies of scale and reduce the cost of gathering and processing information. Large size of the bank helps banks providing larger menu of financial services to their customers, and hence mobilize more funds (Bashir, 1999). The size of the bank is taken as an internal determinant on the assumption that management of the bank is responsible for expanding their organization by acquiring additional assets and liabilities. However, some researchers (Short, 1979 and Bourke, 1989) considered bank size as an external variable. The relationship between the bank size and its profitability is expected to be uncertain as observed in prior studies.

\section{Capital Adequacy}

Rasidah \& Hanafi (2012) claimed that capital is better model as an internal determinant of bank profitability, as increase in profit may lead to an increase in capital. The capital ratio or equity to asset ratio measures the capital adequacy of the bank. It signals the overall shock absorbing capacity of a bank for potential loan asset losses. According to Samad (2004) the higher the capital ratio, the stronger is the ability of the bank to withstand asset losses. Additionally, it could be the case that higher levels of equity would decrease the cost of capital, leading to a positive impact on profitability (Molyneux, 1993). In fact, most studies that use capital ratios as an explanatory variable of bank's profitability (Bourke, 
1989; Molyneux and Thornton; 1992; Goddard et al., 2004) observed a positive relationship with the dependent variable. Also, Athanasoglou et al. (2005), suggest capital as an internal determinant of bank profitability, as higher profits may lead to an increase in capital. However, the risk-return hypothesis assumes that higher profits can be achieved by increasing the risk or leverage of the firm. Thus, a negative relationship between capital and profitability is expected (Ommeren, 2011; Saona, 2011; Sharma and Gounder, 2012).

\section{Loan}

Demirguc-Kunt and Huizinga, 1997 found a positive relationship between the ratio of bank loans to total assets and profitability. Chaudhry et al (1995), discovered a negative relationship of loan with profitability in small and medium sized banks in USA. Nevertheless, Athanasoglou et al. (2006), Vong and Hoi (2009), and Sufian and Habibullah (2009) found a positive relationship between loan and profitability.

Deposit

Smirlock (1985) found that deposits were a cheaper source of funds and had a positive impact on bank profits. However, Heggested (1977) found that banks heavily committed to time and savings deposits earned considerably lower returns compared to banks which have higher dependence on demand deposits.

\section{Expense management}

Bourke (1989), observed a negative relationship between an operating expenses and profitability. He concludes that reduced expenses improve the efficiency and hence raise the profitability of a financial institution. However, Molyneux and Thornton (1992) found a positive relationship, suggesting that high profits earned by firms may be appropriated in the form of higher payroll expenditures paid to more productive human capital. A number of studies have concluded that expense control is the primary determinant of bank profitability as expense management offers a major and consistent opportunity for profitability improvement.

\section{Results And Analysis}

This part of the paper deals with descriptive statistics, correlation analysis and regression analysis performed to establish the relationship between the explanatory variables and dependent variable. 
TABLE I

DESCRIPTIVE STATISTICS

\begin{tabular}{l|c|c|c|c|c|c|c|c}
\hline \multicolumn{1}{c|}{ Variables } & $\begin{array}{c}\text { Mean } \\
(\mathrm{M})\end{array}$ & $\begin{array}{c}\text { Std. } \\
\text { Dev. } \\
(\mathrm{SD})\end{array}$ & Median & Maximum & Minimum & Skewness & Kurtosis & $\mathrm{N}$ \\
\hline Profitability & 0.0169 & 0.0079 & 0.0146 & 0.0354 & 0.0053 & 0.7683 & 2.7678 & 40 \\
Size & 5.0968 & 0.2898 & 5.0738 & 5.8225 & 4.6019 & 0.7942 & 3.4468 & 40 \\
Equity & 0.0836 & 0.0202 & 0.0844 & 0.1323 & 0.0397 & -0.0183 & 2.7508 & 40 \\
Deposit & 0.7753 & 0.1245 & 0.7969 & 0.8856 & 0.0790 & -4.5007 & 25.7880 & 40 \\
Loan & 0.7041 & 0.0579 & 0.7069 & 0.8251 & 0.6008 & 0.2641 & 2.3819 & 40 \\
$\begin{array}{l}\text { Operating } \\
\text { Expense }\end{array}$ & 0.0185 & 0.0058 & 0.0165 & 0.0363 & 0.0120 & 1.3009 & 4.0504 & 37 \\
\hline
\end{tabular}

From the outcomes in Table I, the analysis of the means shows the following descriptive statistics: profitability $(\mathrm{M}=0.0169, \mathrm{SD}=0.0079)$; bank size $(\mathrm{M}=$ $5.0968, \mathrm{SD}=0.2898)$; equity $(\mathrm{M}=0.0836, \mathrm{SD}=0.0202)$; deposit $(\mathrm{M}=0.7753$, $\mathrm{SD}=0.1245)$;loan $(\mathrm{M}=0.7041, \mathrm{SD}=0.0579)$; operating expense $(\mathrm{M}=0.0185$, $\mathrm{SD}=0.0058$;

The analysis reveals that the bank size has the highest mean $(M=5.0968)$, with the deviation from the mean at $28.98 \%$. The lowest standard deviation for operating expense (0.0058) indicates that the data are clustered around the mean and thus more reliable.

TABLE II

THE CORRELATION OF VARIABLES

\begin{tabular}{|c|c|c|c|c|c|c|}
\hline & roa & size & equity & deposit & loan & opex \\
\hline roa & 1.0000 & & & & & \\
\hline size & -0.3893 & 1.0000 & & & & \\
\hline equity & 0.4693 & -0.1352 & 1.0000 & & & \\
\hline deposit & -0.0166 & -0.6216 & -0.1430 & 1.0000 & & \\
\hline loan & 0.2606 & -0.4298 & 0.0678 & 0.5762 & 1.0000 & \\
\hline opex & 0.0681 & -0.2252 & 0.1009 & -0.0714 & -0.4738 & 1.0000 \\
\hline
\end{tabular}

The results in Table II indicate that a negative correlation exists between profitability andtwo of the independent variables (bank size, deposit). Banks profitability has positive correlation with the three explanatory variables of the 
study, (equity, loan and operating expense).Thus, the correlation coefficients indicate that an improvement in bank capital, loan and expense management leads to higher profits for the banks. The simplest and most obvious way to detect multicollinearity is to construct the correlation matrix for independent variable. The correlation of 0.7 and above is considered as highly correlated. Since the correlation values are less than 0.7 , this implies that the multicollinearity among the explanatory variables is not high.

TABLE III

THE REGRESSION RESULTS OF THE FIXED EFFECTS MODEL

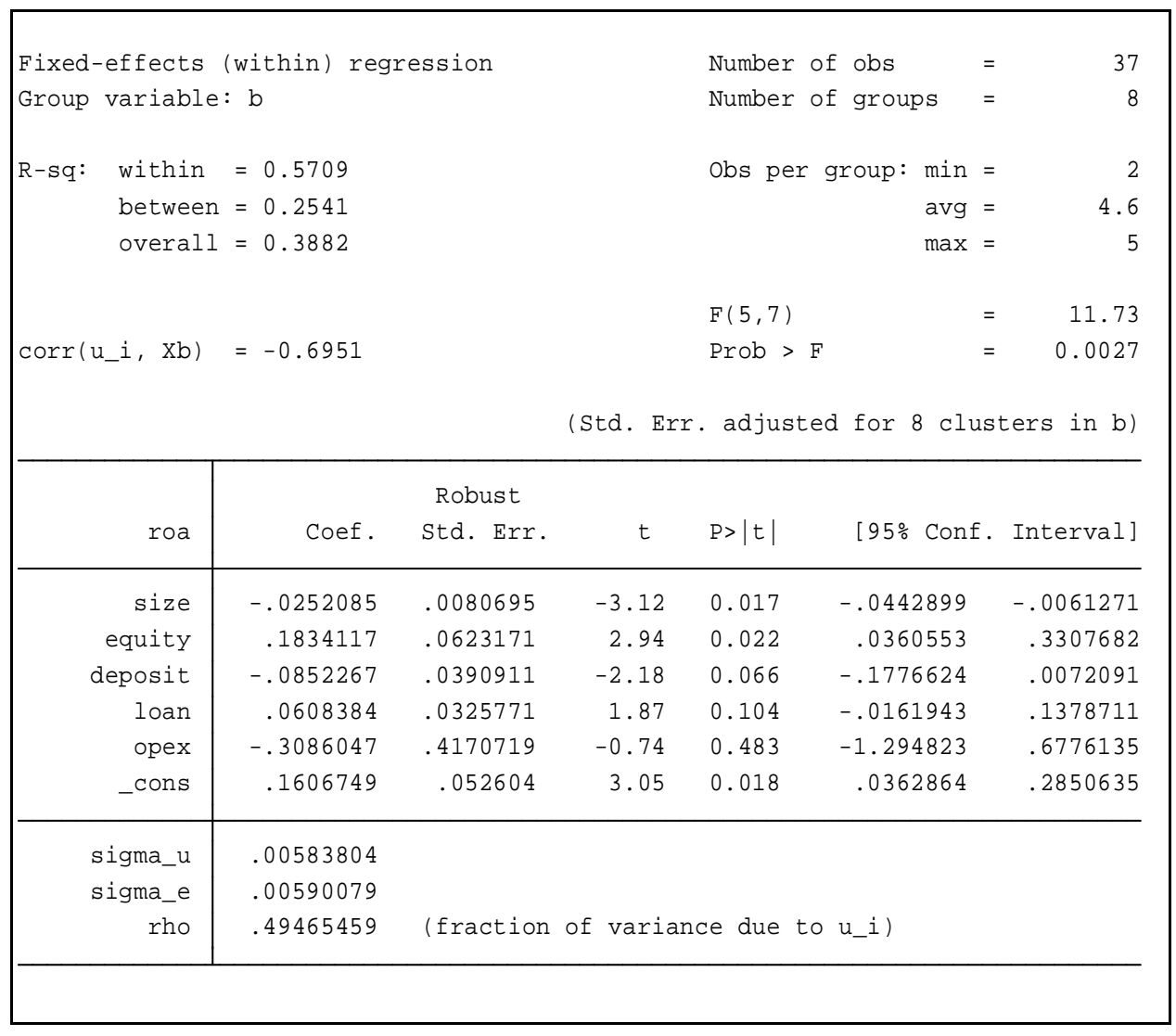

From Table III, the overall regression is statistically significant, $F(5,7)=$ 11.73, Prob $>F=0.0027$, thus agreeing with the fact that bank size, capital structure and deposit are crucial factors in determining the degree of profitability of Islamic banks in Bangladesh. 
Size of bank has a negative effect on banks' profitability (ROA) which is statistically significant. The outcomes indicate that banks are likely to gain fewer profits in comparison to small banks. The negative relationship suggests that, as the banks are becoming very large resulting in their performances negatively. The results are consistent with the works of Staikouras and Wood (2004) and Ani et al. (2012).

The relationship between profitability and capital adequacy is positive and also statistically significant. The results suggest that the banks with larger capital structure are able to expand their business operations by making stronger their ability to assume risk and attract funds at low cost. The outcome is in line with the findings of some studies (Hassan \& Bashir, 2005; Athanasoglouet al. 2005; Dietrich \& Wanzenrid, 2009; Davydenko, 2010; Olweny \& Shipho, 2011; Ommeren, 2011; and Aniet al., 2012). However, the findings are not in line with the outcomes of other studies (Saona, 2011; Ali et al., 2011; Qin \& Pastory, 2012). Staikouras and Wood (2004) argue that a positive coefficient estimate for capital indicates an efficient management of banks' capital.

Deposits as a measure of liquidity impact the profitability significantlynegatively and it goes in contrary to the outcome of prior study of Smirlock (1985).The finding don't correspond to the general assumption that Islamic banks can avail a cost-free fund.

The Loan shows an insignificant positive relationship with ROA of Islamic banks in Bangladesh implying that higher levels of profit are made by the banks when more deposits are transformed into loan. The findings are consistent with the findings of Athanasoglou et al. (2006), Vong and Hoi (2009), and Sufian and Habibullah (2009).

Operating expenses have a negative impact on the performance of Islamic banks in Bangladesh over the period 2009-2013, but the impact is not statistically significant.

\section{CONCLUSION AND RECOMMENDATIONS}

The paper attempted to examine the effect of some selected bank-specific factors including bank size, equity, loan, deposit and operating expense on Islamic banks' profitability. Based on the results of empirical analysis, it is observed that the bank size and deposit have significant inverse impact on the profits of Islamic banks. However, there is significant positive relationship between capital adequacy and profitability. Loan and expense management, on the other hand, do not seem to have significant impact. This finding indicates that improved bank capital contribute to higher bank's performance and growth. 
Larger size of the banks causes the banks to be less profitable implying management's inefficiency to properly utilize the resources. The deposit is seen a liquidity indicator but as a liability. Consequently, it will cause depletion of Islamic banks' profit as cost of fund it counts more. These findings provide some crucial implications for the development and survival of the banks. Such empirical analysis is assumed to add valuable information to the literature about the banking sector in a different context.

The results confirm some previous findings while showing disagreement with others. However, further research can be done by including more bankspecific variables like credit risk, bank charges, interest rate, number of branches and advertisement expenses and external-macroeconomic variables as well covering longer time period.

\section{REFERENCES}

Al-Jarrah, I.M., Ziadat,K. N. and El-Rimawi, S.Y. (2010). The Determinants of the Jordanian's Banks Profitability: A Cointegration Approach. Jordan Journal of Business Administration, 6(2).

Ali, K., Akhtar, M. F. and Ahmed, H. Z. (2011).Bank Specific and Macroeconomic Indicators of Profitability - Empirical Evidence from the Commercial banks of Pakistan.International Journal of Business and Social Science, 2(6), 235 - 242.

Alper Deger \& Anbar Adem. (2011). Bank Specific and Macroeconomic Determinants of Commercial Bank Profitability: Empirical Evidence from Turkey. Business and Economics Research Journal, 2, 139-152

Ani, W.U., Ugwunta, D.O., Ezeudu, I. J. and Ugwuanyi, G. O. (2012). An Assessment of the Determinants of bank Profitability in Nigeria: Bank Characteristics Panel Evidence. Journal of Accounting and Taxation, 4(3), 38 - 43.

Athanasoglou , P.P., Delis, M. D. and Staikouras, C., "Determinants of Bank Profitability in the South Eastern European Region", Journal of Financial Decision Making, Vol. 2, 2005, pp.1-17.

Athanasoglou, P., Delis M. and Staikouras, C. (2006).Determinants of Banking Profitability in the South Eastern European Region.Bank of Greece Working Paper 06/47.online at htty://mpra.ub.uni-muenchen.de/10274.

Athanasoglou, P., Brissimis, N., Delis, D. (2008), Bank-Specific, Industry-Specific and Macroeconomic Determinants of Bank Profitability. International Financial Markets Institutions and Money, 18, 121-136. 
Bashir, A. 1999. "Risk and Profitability Measures in Islamic Banks: The Case of Two Sudanese Banks." Islamic Economic Studies, Vol. 6, No. 2: 1-24.

Boyd, J., and D. Runkle (1993), "Size and Performance of Banking Firms: Testing the Prediction of the Theory", Journal of Monetary Economics, Vol. 31, pp. 47-67.

Bourke, P. (1989), Concentration and other Determinants of Bank Profitability in Europe NorthAmerica and Australia.Journal of Banking and Finance, 13(1), 66-79.

Chaudry, M., Chatrath, A. and Kamath, R., "Determinants of Bank Profitability", American Journal of Business, Vol. 10, No.1, 1995, pp.41-46.

Davydenko, A. (2010). Determinants of Bank Profitability in Ukraine. Undergraduate Economic Review, 7(1/2). Available at: http://digitalcommons.iwu.edu/uer/vol7/iss1/2

Dawood, U. (2014). Factors Impacting Profitability of Commercial Banks in Pakistan for the Period of (2009-2012).International Journal of Scientific and Research Publications, 4(3).

Demirguc-Kunt, A., and V. Maksimovic (1996), 'Stock Market Development and Financing Choices of Firms', The World Bank Economic Review, 10 (2), 341369.

Goddard, J., Molyneux, P., \& Wilson, J. (2004).Dynamic of growth and profitability in banking.Journal of Money, Credit and Banking 36, 1069-1090.

Heggested, Arnold A., (1977), "Market Structure, Risk, and Profitability in CommercialBanking”, Journal of Finance, Vol. 32, p. 1207-1216.

Heffernan, S. and Fu, M. (2008). "The determinants of bank performance in China”. Working Paper Series, (WP-EMG-03-2008), Cass Business School,.City University, $U K$.

Kosmidou K., Sailesh,T. and Fation, P. (2006) .Determinants of profitability of domestic UK commercial bank: panel evidence from the period 1995-2002. Applied Research

workingpaperseries.http://www.coventry.ac.uk/cu/external/content/1/c4/09/52/v 1204731103/user/RP2008 4.pdf

Lipunga, A. M. (2014). Determinants of Profitability of Listed Commercial Banks in Developing Countries: Evidence from Malawi. Research Journal of Finance and Accounting, 596.

Macit, F. (2011). Bank Specific and Macroeconomic Determinants of Profitability: Evidence from Participation Banks in Turkey. Economics Bulletin, 32(1). 
Mohammad Nayeem Abdullah, Kamruddin Parvez and Salma Ayreen (2014), "Bank Specific, Industry Specific and Macroeconomic Determinants of Commercial Bank Profitability:A Case of Bangladesh"World Journal of Social Sciences Vol. 4. No. 3.October 2014 Issue. Pp. 82 - 96

Molyneux P. (1993). "Structure and performance in European banking."Doctoral Dissertation, University of Wales, Bagnor.

Molyneux, P., and J. Thornton (1992), 'Determinants of European bank Profitability: A Note', Journal of Banking and Finance (16), 1173-1178.

Mouri Dey (2014), "Profitability of Commercial Banks in Bangladesh:A Multivariate Analysis" IOSR Journal of Business and Management (IOSR-JBM) e-ISSN: 2278-487X, p-ISSN: 2319-7668. Volume 16, Issue 4. Ver. III (Apr. 2014), PP 92-95

Ommeren, S. V. (2011). An Examination of the Determinants of Banks' Profitability in the European Banking Sector, An Unpublished M. Sc. Thesis, Department of Accounting and Finance, Erasmus School of Economics Erasmus University, Rotterdam.

Peters, D., Raad, E. \&Sinkey F. Joseph.(2004). "The performance of banks in post-war Lebanon”.International Journal of Business, 9(3), 259-286.

Putranto, A., Herwany, A. and Sumirat, E. (2014).The Determinants of Commercial Bank Profitability in Indonesia.Faculty of Economics and Business, UniversitasPadjadjaran, Indonesia. Available at: http://ssrn.com/abstract $=2456092$

Rasidah Mohd Said \& Mohdhanafi Tumin. (2011). Performance of financial ratios of commercial banks in malaysia and china. International Review of Business Research Papers, 7(2), 157-169.

Samad, A. (2004). "Performance of interest-free Islamic banks vis-à-vis interest-based conventional banks of Bahrain". IIUM Journal of Economics and Management, $12(2), 1-15$.

Saona, P. H. (2011). Determinants of the Profitability of the US Banking Industry.International Journal of Business and Social Science, 2(22), 255 - 269.

Sharma, P. and Gounder, N. (2012). Profitability Determinants of Deposit Institutions in Small, Underdeveloped Financial Systems: The Case of Fiji. Griffith Business School Discussion Papers Finance, No. 2012 - 06. Available at: http://equella.rcs.gri\&th.edu.au/research/items/ ... financial systems. pdf.

Shrimal Perera, Michael Skully and Zahida Chaudhry (2013), Determinants of Commercial Bank Profitability: South Asian Evidence. Asian Journal of Finance \& Accounting, ISSN 1946-052X 2013, Vol. 5, No. 1 
Short, B. K. (1979).'The relation between commercial bank profit and banking concentration in Canada, Western Europe and Japan'.Journal of Banking and Finance, 3, 209-219.

Smirlock, M. (1985), "Evidence on the (Non) Relationship between Concentration and Profitability in Banking", Journal of Money, Credit and Banking, Vol. 17, p. 6983.

Staikouras, C. K. and Wood, G. E. (2004). The Determinants of European bank Profitability. International Business and Economic Research Journal, 3(6), 57 68.

Sufian, F. and Habibbullah, M. S., "Bank Specific and Macroeconomic determinants of bank profitability: Empirical evidence from the China banking sector", Frontiers of Economics in China, Vol. 2, 2009, pp. 274-291.

Sufian, G. (2011).The Profitability of Korean Banking Sector.Journal of economic and management, 7(1), 43-72.

Vong, P. I. A. and Hoi, S. C. "Determinants of Bank Profitability in Macao", University of Macao working paper, July 2009.

Yilmaz,A., A.(2013). Profitability Banking System Evidence from Emerging Markets.WEI International Academic Conference Proceedings, Antalya, Turkey.

Z. R. Imad, "Bank-specific determinants of Islamic banks profitability: an emperical study of the Jordanian market," International Journal of Academic Research, vol. 3, no. 6, pp. 73-80, 2011. 


\section{APPENDIX}

a) List of banks Included in the study.

\begin{tabular}{|c|l|}
\hline Sl. & \multicolumn{1}{|c|}{ Name of banks } \\
\hline 1 & Al-Arafah Islami Bank Limited \\
\hline 2 & Export Import (EXIM) Bank of Bangladesh Limited \\
\hline 3 & International Finance Investment and Commerce (IFIC) Bank Limited \\
\hline 4 & Islami Bank Bangladesh Limited \\
\hline 5 & Shahjalal Islami Bank Limited \\
\hline 6 & AB bank limited \\
\hline 7 & First Security Islami Bank \\
\hline 8 & Social Islami Bank limited (SIBL) \\
\hline
\end{tabular}

b) Screenshot of various test performed to support the model applied in the study includes the following.

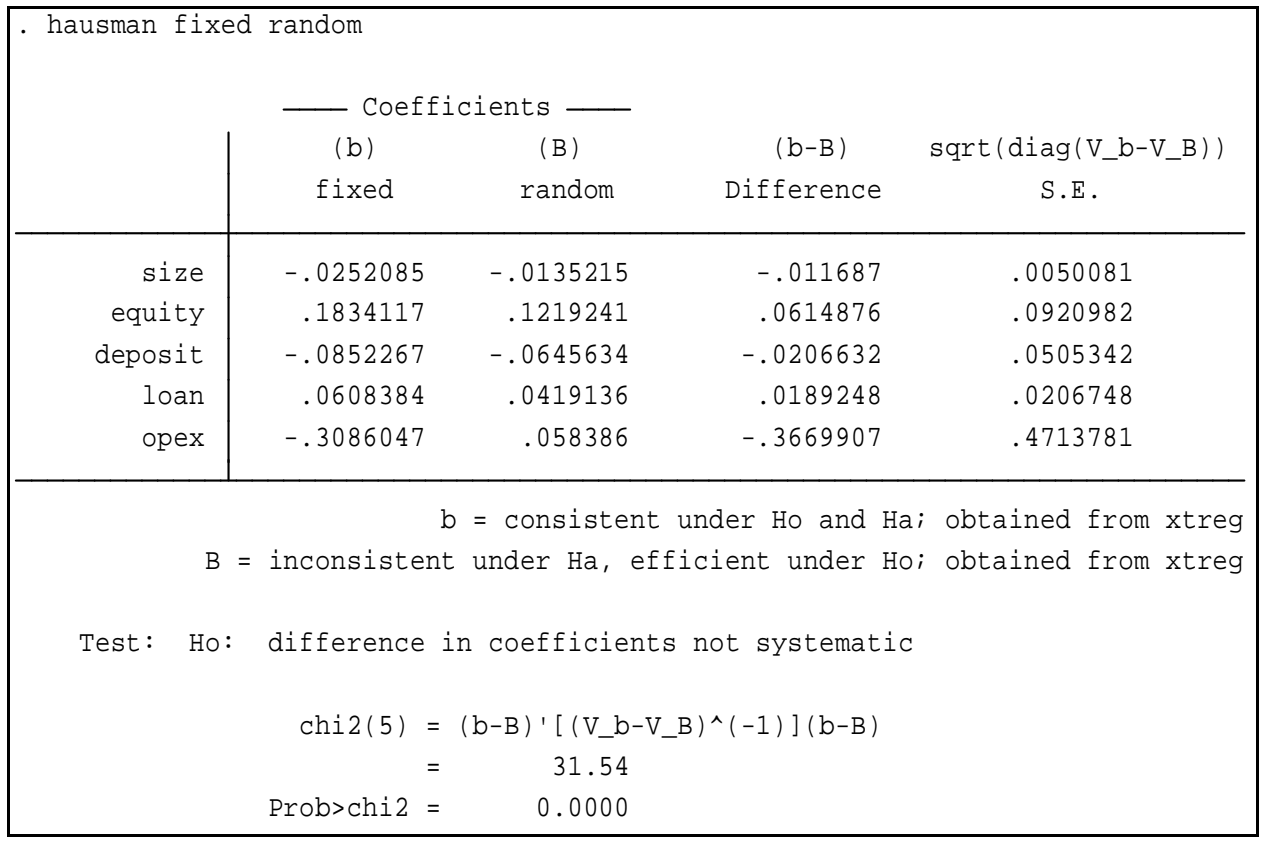




\begin{tabular}{|r|cr|}
\hline Variable & VIF & $1 /$ VIF \\
\hline loan & 2.51 & 0.397781 \\
deposit & 2.27 & 0.441196 \\
size & 2.23 & 0.448800 \\
opex & 1.84 & 0.542605 \\
equity & 1.16 & 0.862856 \\
\hline Mean VIF & 2.00 & \\
\hline
\end{tabular}

Modified Wald test for groupwise heteroskedasticity

in fixed effect regression model

HO: sigma(i)^2 = sigma^2 for all $i$

chi2 (8) $=724.82$

Prob>chi2 $=0.0000$

Wooldridge test for autocorrelation in panel data

HO: no first-order autocorrelation
F ( 1,
6) $=$
0.188
Prob $>\mathrm{F}=$
0.6801 